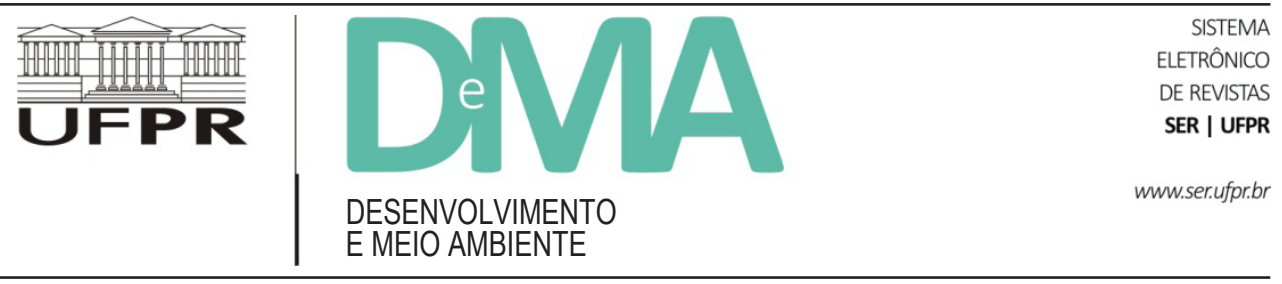

\title{
The Payments for Environmental Services Program in Costa Rica: an Assessment of the Program's Early Years ${ }^{1}$
}

\section{O Programa de Pagamentos por Serviços Ambientais na Costa Rica: uma avaliação dos primeiros anos do programa}

\author{
Carolina Antony FONSECA ${ }^{1}$, José Augusto DRUMMOND²* \\ ${ }^{1}$ Secretaria Geral da Presidência da República, Brasília, DF, Brasil. \\ ${ }^{2}$ Centro de desenvolvimento Sustentável, Universidade de Brasília (UnB), Brasília, DF, Brasil. \\ *E-mail of contact: jaldrummond@uol.com.br
}

Article received June 30, 2014; final version accepted November 3, 2014.

ABSTRACT: Costa Rica's Payment for Environmental Services Program-PESP was launched in 1997. It is a market-oriented policy instrument designed to stimulate forest conservation by making monetary payments to landowners who choose not to engage in deforestation or to engage in forest recovery or plantations on their properties. This article focuses on the basic concepts and on the early years of the program's performance, using data published by the program's management agency as well as data and analysis published in a limited number of the numerous texts that examine this pioneering experience in payments for environmental services. Findings show that in its early years (between 1997 and approximately 2003) the program managed to reverse a severe process of deforestation and even expand the total area of forested lands in Costa Rica. It corrected market failures and created trade opportunities linked to the market of environmental services. It benefitted larger landowners in a more than proportional manner, a fact that precluded it from being simultaneously a poverty alleviation program. The conclusion is that the program, if targeted more precisely at small landowners, can serve as a model for comparable forest protection policies in developing countries, reducing deforestation rates, changing land uses and expanding forest cover, besides mitigating rural poverty.

Keywords: economic policy instruments; poverty alleviation; deforestation; Costa Rica; payment for environmental services.

RESUMO: O Programa de Pagamentos por Serviços Ambientais (PESP) da Costa Rica foi lançado em 1997. Trata-se de uma política orientada para o mercado que visa estimular a conservação de florestas por meio de pagamentos feitos diretamente a donos de terras que optam voluntariamente por não se engajar em ações de desmatamento ou que se engajam em ações de recuperação florestal ou de plantios de árvores. Este artigo focaliza os conceitos

\footnotetext{
${ }^{1}$ The authors thank Ghazal Badiomazani for her participation in the drafting of an earlier version of this text.
} 
básicos do programa e no seu desempenho em seus primeiros anos, usando como bases dados publicados pela gerência do programa e um número restrito dos numerosos textos que analisam e avaliam essa experiência pioneira em PSA. Os achados mostram que o programa conseguiu reverter um quadro agudo de desmatamento que vinha ocorrendo desde a década de 1960; entre 1997 e 2003, aproximadamente, contribuiu até para uma expansão líquida da área florestada do país. Além disso, ele corrigiu falhas de mercado e criou oportunidades para transações ligadas ao mercado de serviços ambientais. Foi constatado ainda que os maiores donos de terra engajados no programa foram beneficiados de uma forma mais do que proporcional aos seus números e que isso impediu que o programa assumisse o caráter simultâneo de mitigação da pobreza rural. A conclusão é que o programa, se direcionado com maior precisão para os pequenos proprietários de terra, é justificadamente adotado como referência e modelo para políticas comparáveis de proteção florestal em países em desenvolvimento, reduzindo os índices de desmatamento, mudando usos da terra, expandindo a cobertura florestal e mitigando a pobreza rural.

Palavras-chave: instrumentos econômicos; mitigação da pobreza; desmatamento; Costa Rica; pagamento por serviços ambientais.

\section{Introduction - a new forest protection policy}

In the 1960s and 1970s, Costa Rica had one of the highest rates of deforestation in the world (Rosero-Bixby \& Poloni, 1998, p. 2). Since 1969, however, a new set of policies and regulations has evolved into direct measures, resulting in a substantial reduction of those rates. By the early 2000s, Costa Rica recorded an auspicious net gain in forest cover (FAO, 2005, p. 200). A key tool for reaching such a result was the creation, in 1969, of a system of public protected areas (herein referred to as SINAC), in which logging is strictly prohibited (Ulate, 1997, p. 25).

However, as $75.7 \%$ of Costa Rica's forests are privately owned (FAO, 2005, p. 206), the Costa Rican government had to create policies to tackle logging in private lands. For this purpose, it created a system of incentives for conservation and forestry activities, including a program of direct payments made to private landowners in exchange for the provision of environmental services by the forests they choose to maintain on their properties. The origins and early performance of this program are the major topics of this article. It became the major precursor of more recent and widely publicized programs that fall under the general name of "Payments for Environmental Services" - PES, now adopted in several countries. Since 1997, Costa Rica's "Programa de Pagos por Servicios Ambientales" (herein referred to as PESP - Payment for Environmental Services Program) has succeeded in protecting 599,061.50 ha, 23 per cent of Costa Rica's total forested area of 2,391,000 ha). ${ }^{2}$ (FONAFIFO, 2007)

This article reviews part of the analytical literature about economic instruments used in the early years of Costa Rica's PESP. It also examines official and unofficial data presented in several case studies that focus on those early years. Information from the program's site on the Internet was also used. The focus fell upon types of payments, numbers of beneficiaries, and the equity of payments (given the differences among beneficiaries in terms of the sizes of their land holdings and of family income). It also emphasizes three important aspects of the program: institutional complexity and strengthening, economic impacts for beneficiaries, and environmental consequences. This research seeks to help understand PESP's success in its early years, in terms of the protection and recovery of forest cover. This may help assess its relevance as a reference or model for similar natural resource protection programs in other countries.

The pertinent literature argues that the forest conservation and recovery program in Costa Rica was successful for two main reasons: (i) it changed the

\footnotetext{
${ }^{2}$ General information about the program, including data on numbers of applications, monetary disbursements and the amount of areas included in the program until $2009 \mathrm{can}$ be found in http://www.fonafifo.com/paginas_espanol/servicios_ambientales/sa_estadisticas.htm, June 262014 .
} 
predominant use of forested lands from clear cutting to conservation, and (ii) legal improvements and increased institutional strength allowed adequate PESP implementation. The literature also argues that PESP has two weaknesses: (i) it benefits landowners who would probably protect natural resources in their lands even if PESP did not exist, and (ii) it does not give priority to small and medium land-owners and to forest-dependent communities, as it was conceived to do when it was created, since a large proportion of the actual payments goes to large landowners. Besides critically examining the two reasons for success and the first of the aforementioned weaknesses, we point out that the second shortcoming barred the program from attaining the additional and socially relevant status of a poverty mitigation strategy.

This article has five sections, the first one being this introduction. The second one discusses briefly the literature about economic instruments for conservation. The third section provides a profile of Costa Rica's deforestation control strategies. The fourth section examines how legal improvements and institutional strengthening contributed to the success of PESP and to the decline of deforestation rates. Lastly, the fifth section discusses the limitations and the potentials of PESP - and PES programs in general - as an instrument for poverty mitigation.

\section{Economic instruments for conservation purposes}

There are three basic types of policies to avoid or mitigate the negative environmental impacts of productive activities: command-and-control regulations, economic or market-based instruments, and educational instruments (Romeiro, 2003; Palm \& Larsson, 2007). Command-and-control instruments are straightforward regulations that must be followed by polluters - standards, rules, bans, procedures and controls. Sanctions apply if rules are not observed (Lustosa et al., 2003). Economic or market-based instruments are "regulations that encourage behavior through market signals rather than through explicit directives regarding pollution control levels or methods" (Stavins, 2002, p. 1). Educational or informative instruments form a broad set of policies and practices that fall under the heading of environmental education, in which relevant information on the avoidance and the mitigation of environmental problems is provided to the general population or to targeted social groups, with the hope of altering their behavior patterns.

Classical economic theory states that the scarcity of a product leads to the increase of its price, thus balancing its supply and demand. In theory, the scarcity of certain environmental goods could be compensated by these increased prices, leading to their moderate use or even to their substitution by abundant materials (when feasible). Nevertheless, market mechanisms tend to fail to regulate supply and demand of environmental goods and services not generated by human labor, causing demand to outstrip the supply of non-renewable goods and even the regenerative capability of renewable resources. Examples abound - biodiversity, agricultural soils, and the capacity of forests to produce oxygen and remove carbon dioxide from the atmosphere. These items are not tradable in traditional markets, because they are public goods. They are not attributable to human labor or investments and thus their economic value is hard to define in a market setting. Community or government intervention is therefore required to correct these market failures and to establish and/or increase the prices of environmental goods and services, so that they will remain available to present and future generations (Daly, 1996).

Although environmental economists and ecological economists disagree among themselves about the viability of technological and scientific solutions for natural resource constraints, they agree on a crucial point - it is important to create a regulatory structure based on economic incentives to guarantee efficiency in the use of natural resources (Romeiro, 2003). Many governments have tried different instruments that seek to reduce the negative impacts of modern industry and agriculture on the environment. The Costa Rican government, for example, uses several economic instruments, such as pollution taxes, subsidies, marketable permits and performance bonds. They seek to realign market signals and promote environmentally responsible behavior (MINAE, 2002).

Payments for environmental services - PES is a financial mechanism that acknowledges and rewards the environmental services provided by ecosystems 
to society at large (Wunder, 2005). The two main principles of PES are: (1) providers of environmental services should be compensated and (2) recipients of those services should pay for them. Costa Rica's PESP, for example, has achieved a significant degree of success in stimulating forest conservation in privately owned lands. It compensates landowners financially for the environmental services generated by their privately owned forests (Wunder, 2005).

Ferraro \& Kiss (2002) state that a direct approach such as PES is more effective than conserving biodiversity in public protected areas or indirect investments, such as subsidies or fiscal incentives. We maintain that this mechanism may have a secondary - but not less important - goal: mitigation of poverty, specifically rural poverty. To achieve both goals, PES must target areas characterized by both (i) a high risk of degradation and (ii) a significant volume of environmental services and goods, especially in places where low income or small landowners are potential beneficiaries. This research examines these issues as they appear in the context of Costa Rica's PESP.

As a pioneering policy instrument for payments for environmental services, Costa Rica's PESP has attracted wide attention among scholars, policy makers, cooperation agencies, managers etc. It also has influenced policy discussions and decisions in several countries. Because we focus on certain aspects of the early years of PESP's implementation, our goal is neither a comprehensive examination of PESP's origins, nor of its overall performance to date.

Pagiola (2006) focused on analysing PESP's early years. A representative example of more comprehensive approaches to the study of PESP is Le Coq et al. (2012). ${ }^{3}$ The authors examine the emergence of Costa Rican forest law 7,575, attributing it to a combination of four factors local awareness of the severity of deforestation, existence of earlier forest policies that generated well structured interest groups, circulation of Costa Rican nationals and international environmental policy networks, and the existence of "policy entrepreneurs" who were able to pull together local and international ideas and proposals and to insert them in a new policy framework. Our study acknowledges the second factor and suggests that some of the more powerful interest groups may have been responsible for PESP's biased disbursement record, which favored medium- and large-scale landowners.

A recent paper, written by Aguilar-Støen et al. (2013), links PES programs in Costa Rica and Colombia to emerging REDD and REDD+ proposals and programs in the same countries. It is based on thorough research on several pertinent governance dimensions of PES, REDD and REDD+ (particularly the inclusion of poorer farmers and indigenous peoples). It focuses also on the ways that these programs relate to each other in the simultaneous goals of preserving existing native forest cover and reaching net gains in the area of forested lands (native, secondary and planted/managed).

Another recent collection of studies about PES and REDD was published in a dossier in 2013. ${ }^{4}$ The focus is mainly on PES initiatives and proposals in several locations of the Brazilian territory. Nonetheless, several articles use and describe Costa Rica's PESP as an inspiration for similar experiences in Brazil or as a reference for comparative analysis. The article by the dossier editors (Eloy et al., 2013) may be cited for the close attention it gives to Costa Rica's PESP. Pereira (2010) is a quite critical study of two PES programs in the Bolivian and Brazilian Amazon regions also strongly referenced to the Costa Rican experience. The author warns that these programs may be affected by perceived PESP shortcomings, such as bringing only limited benefits to rural and forest dwellers and promoting the interests of government agencies and segments of local elites.

\section{Costa Rica's conservation strategies: PESP's contribution to the control of deforestation}

The Costa Rican national territory has a total area of 5,106,000 ha. In 2010, 2,605,000 ha were classified as forested lands (51.01 percent). Total forest cover oscil-

\footnotetext{
${ }^{3}$ This article is part of a dossier published in the same issue of the journal VertigO, under the title "Émergence et mise en politique des services environnementaux et écosystémiques". An expanded version of this study, including different authors, is Le Coq et al. (2011).

${ }^{4}$ The title of the dossier is "Pagamentos por Serviços Ambientais no Brasil" [Payments for Environmental Services in Brazil], edited by Emilie Coudel, Fabiano Toni, Ludivine Eloy. See Sustentabilidade em Debate, 4(1), 17-159 (2013).
} 
lated slightly between 1990 and 2005 - from 2,564,000 ha to $2,491,000$ ha, increasing to $2,605,000$ in 1990 , 2005 and 2010, respectively. However, the annual rate of deforestation changed from 19,000 ha/year in 19902000 to a positive reforestation rate of 3,000 ha/year in 2000-2005 and in 2006-2010. Between 2000 and 2005 , no primary forests were cut; the area dedicated to agriculture increased in only 1,000 ha. ${ }^{5}$ Between 1990 and 2010 , the country lost a yearly average of 2,050 ha of forests, or just $0.08 \%$. For the same period, however, Costa Rica gained $1.6 \%$ in its total forest cover, or around 41,000 ha (about 2,000 ha per year) (Butler, 2014; FAO, 2005). The government's conservation and reforestation efforts played a major role in this transition from forest loss to forest recovery.

Over the last 40 years, four laws affected Costa Rica's forest protection and management policies: Laws 4,465/1969, 7,032/1986, 7,174/1990 and 7,575/1996 (MINAE, 2002, p. 4). The first law created a system of protected public areas (Ulate, 1997, p. 25). It placed $1,279,886$ ha under protection, about 25 percent of the national territory that nowadays corresponds to public protected areas (COSTA RICA, 2007, p. 377). Laws $7,032 / 1986$ and 7,174/1990 defined rules for forest management and reforestation on private lands. Law 7,032 created a federal forest agency to supervise forestry activities, such as management and plantations. In 1996, Law 7,575 defined this agency as the National Forestry Financing Fund (referred here as FONAFIFO ${ }^{6}$ ). FONAFIFO's history and missions are discussed later in this article.

2005 data showed that 75.7 percent of forested Costa Rica lands and 60 percent of lands covered by other woody vegetation were privately owned (FAO, 2005, p. 206), a situation that seems to have changed little since. This indicates the significance of Costa Rica's strategy to encourage reforestation and conservation specifically in private properties.

Like other developing countries in Latin America, Costa Rica's economy in the past was based mainly on the production of primary commodities aimed at foreign markets. Historically it experienced high deforestation rates. During the 1970s and early 1980s, vast sections of its rainforests were still being burned and converted into croplands and pastures. ${ }^{7}$ After 1992, the importance of agriculture, cattle ranching and timber harvesting decreased, while other economic activities, such as ecotourism, increased (MINAE, 2002, p. 5).

The relation between deforestation and productive activities is telling. Although the findings by Rosero-Bixby and Palloni about the relationship between population growth and deforestation in Costa Rica between 1973 and 1983 are not conclusive, they provide insight about the matter. They found that "land tenure and relations of production are important for the population-deforestation connection" (Rosero-Bixby \& Palloni, 1998, p. 17). They could not demonstrate the direct impact of population growth on forest loss, but showed that both are indirectly related, as population growth demands increasing amounts of natural resources, making resource output grow at the same rate.

Persson \& Munasighe (1995, p. 263) examined how public policies can help control deforestation. They blame four activities for most of the deforestation in Costa Rica: logging, banana plantations, cattle ranching, and squatting. Together with market failures, government negligence, property rights issues and unemployment (Persson \& Munasighe, 1995, p. 260), these activities compose an ideal formula for environmental devastation. The results of a computable general equilibrium (CGE) model applied by the authors indicated that correcting the market would reduce deforestation. This is what Costa Rica's government did since 1997, when it launched PESP, at a relatively early moment in the still recent global history of tropical forest protection efforts.

The Costa Rican government interprets payments for environmental services as a financial retribution to private landowners who preserve environmental goods and services by maintaining or enlarging forest cover on their lands ${ }^{8}$ (FONAFIFO, 2008). According

\footnotetext{
${ }^{5}$ http://rainforests.mongabay.com/deforestation/2000/Costa_Rica.htm, June 262014.

${ }^{6}$ The acronym comes from its name in Spanish - Fondo Nacional de Financiamiento Forestal - FONAFIFO.

${ }^{7} \mathrm{http}: / /$ rainforests.mongabay.com/20costarica.htm, June 262014.

${ }^{8} \mathrm{http} / / /$ www.fonafifo.com/paginas_espanol/servicios_ambientales/servicios_ambientales.htm, June 262014.
} 
to FONAFIFO, the program's most important feature is that the 1996 Forest Law replaced concepts such as "subsidy" (tax reductions), used to finance forestry activities since 1979, with the concept of "economic acknowledgment" of environmental services provided through forest conservation ${ }^{9}$ (FONAFIFO, 2008). The government has stated that the difference between the two approaches is that the new one rewards financially owners for conserving forests, while the former one sought to stimulate irresponsible forest management. At the same time, Rojas \& Aylward (2003, p. 98) noted that PESP "seems to be a continuation of the subsidy scheme to the forestry sector", since landowners are allowed to engage in logging if they choose to abandon the program when PESP contracts expire.

PESP considers environmental goods as those products that can be consumed or commercialized by humans, such as timber, fruits, seeds, medicines etc. Environmental services are those provided by the ability of healthy ecosystems to generate those goods. ${ }^{10}$ The services targeted by PESP are mitigation of greenhouse effect gases, carbon sequestration, protection of water resources, protection of biodiversity, and provision of scenic beauty (MINAE, 2002, p. 39). These are the same types of environmental services identified by Wunder (2005).

Initially, PESP adopted three types of contracts: forest protection, forest management, and reforestation through plantations. In 2003, MINAE discontinued forest management contracts. This was in part influenced by the critique made by The Costa Rican Federation for Nature Conservation (FECON), which argued that a profitable activity, such as forest management, should not receive payments for environmental services and that PESP should be directed mainly at forest conservation (COSTA RICA, 2002, p. 245). In the same year, PESP created a new type of contract - agroforestry systems would receive a financial reward for each tree planted (instead of the area protected, as in the other PESP contracts). The decision to accept agroforestry systems in PESP seems to us inconsistent with the exclusion of forest management, because both are profitable activi- ties. Nonetheless, agroforestry systems continued to be supported by PESP.

Since 2006, reforestation projects were divided into three sub-categories: reforestation with native species, natural recovery of productive areas, and natural recovery of pastures (FONAFIFO, 2007). Another interesting change came about after 2000, when early policy evaluations pointed to the fact that indigenous communities and women were underprivileged groups that should become PESP beneficiaries. Accordingly, they became special targets for PESP initiatives (Carvajal et al., 2003, p. 10).

According to the PESP manual, individuals and small to medium landowners' associations can benefit from payments. To access PESP, applicants must submit a written petition describing the beneficiaries, the area (size and location) and the desired contract type. A detailed management plan drafted by a licensed forester is also required (FONAFIFO, 2003, p. 4, 6). Every year, the government defines the total funding for PESP: the amount available for each type of contract, the amount paid for each planted tree in agro-forestry systems or for each hectare protected or reforested, the length of the contracts, number of payments to be made, priority areas, and deadlines for submissions. (MINAE. Decree 31,081/2003; Decree 31,767/2004; Decree 32,226/2005; Decree 32,226/2006; Decree 33,852/2007; Decree 34,371/2008).

Priority areas vary for each kind of contract, covering a wide range of land uses. Since 2006, areas for reforestation are selected preferably among those with a high potential for plantations or those with expired reforestation agreements funded by the government. Areas that have low "Social Development Index" scores (less than 40 percent) are also eligible. Since 1997, areas labeled as "Kyoto lands" (deforested before 1990) have received special consideration - they have gained priority for being selected for reforestation with native species. When the major goal is protection, priority is given to biological corridors, watersheds, private lands within public conservation areas, areas with low "Social Development Index" scores, and areas benefited by expired

\footnotetext{
${ }^{9} \mathrm{http}: / / \mathrm{www}$. fonafifo.com/paginas_espanol/servicios_ambientales/sa_concepto.htm, June 262014.

${ }^{10} \mathrm{http}: / /$ www.sirefor.go.cr/serviciosambientales.html, June 262014.
} 
protection contracts with PESP. Also worthy of priority status are agroforestry projects designed by producers' associations that hold valid contracts with FONAFIFO to work on lands with poor soils. (MINAE. Decree 32,226/2006; Decree 33,852/2007; Decree 34,371/2008; FONAFIFO, 2006; MAG-MIRENEM, 1995).

In the mid 2000s, PESP was paying US\$ 320 per protected hectare, US\$ 816 per reforested hectare, US\$ 816 per hectare of naturally regenerated productive soil, ${ }^{11}$ US\$ 205 per hectare of naturally recovered pastures, and US\$ 1.30 per planted tree in agro-forestry systems. ${ }^{12}$ FONAFIFO can pay other amounts, depending on specific agreements with donors (MINAE. Decree 31,081/2003; Decree 31,767/2004; Decree 32,226/2006; Decree 33,852/2007; Decree 34,371/2008).

The 2007 PESP manual (FONAFIFO, 2007) defined that the minimum area for reforestation projects is $1 \mathrm{ha} /$ year and the maximum is $300 \mathrm{ha} /$ year; for reforestation projects submitted by small and medium landowner associations, the maximum is $50 \mathrm{ha} /$ year for each property; for forest protection, the minimum is $2 \mathrm{ha} /$ year and the maximum is $300 \mathrm{ha} /$ year; for natural regeneration of productive areas and pastures, the minimum is $2 \mathrm{ha}$, with no maximum; for agro-forestry systems, the minimum is 350 planted trees and the maximum is 3,500 trees, per beneficiary. In 2010, the minimum and maximum areas were still the same (see Table 1).
The monetary values found in the last column were estimated by PESP policy designers and managers on the basis of (i) the market values of logs from different species of trees (either planted, naturally recovering, or native), in combination with (ii) the average market values of land. Of course, in the case of pasture recovery on deforested lands, only the second criteria is applicable. Individual contracts specified single-objective protection measures and payment values were based on this option. If individual landowners took out more than what the contract stipulated, indicating commitment to multiple protection measures (our data did not confirm that this happened), we did not find information about how this affected computations of the values to be paid to them.

According to basic PESP documents, contracts usually last five years, with the possibility of extension for five more years. In 2006, agroforestry systems contracts were being signed exceptionally for periods of three years. Another exception is adopted for reforestation projects, which can be implemented for a maximum of 15 years, as they demand more time to achieve results (MINAE. Decree 34,371/2008).

Disbursements to beneficiaries are made in annual payments, according to each category of PESP and to the year in which the agreements were signed. Protection and natural regeneration contracts settled in 2006, for example, received 20 percent of the total amounts due

TABLE 1 - Costa Rica's PESP: Minimum and Maximum Areas or Number of Trees Supported and Respective Amounts Paid, per Type of Contract, 2007-2010

\begin{tabular}{|c|c|c|c|c|}
\hline & type of contract & minimum & maximum & amount paid \\
\hline & agro-forestry systems & 350 trees & 3,500 trees & $1.30 \mathrm{USD} /$ tree \\
\hline & protection & 2 ha & 300 ha & 320 USD/ha \\
\hline \multirow{6}{*}{ reforestation } & with native species & $1 \mathrm{ha}$ & 300 ha & 816 USD/ha \\
\hline & natural recovery of productive areas & 2 ha & --- & $816 \mathrm{USD} / \mathrm{ha}$ \\
\hline & natural recovery of pastures & 2 ha & --- & 205 USD/ha \\
\hline & projects submitted by small & & 50 ha for each & $816 \mathrm{USD} / \mathrm{ha}$ \\
\hline & and medium landowners' & ---- & property & or* \\
\hline & associations & & & $205 \mathrm{USD} / \mathrm{ha}$ \\
\hline
\end{tabular}

*Depending on type of reforestation.

SOURCE: FONAFIFO, 2007.

\footnotetext{
${ }^{11}$ Except in 2006, when FONAFIFO paid US\$205,00 per hectare of naturally regenerated productive soil.

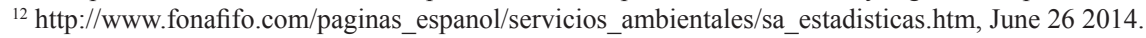


per year, for five consecutive years. In the same year, reforestation projects received 46 percent of payments upfront and should receive the rest at the rate of 6 percent annually, from the second to the tenth year. Agroforestry systems contracts signed in 2006 received 65 percent of the total amounts upfront in the first year, 20 percent in 2007 and 15 percent in $2008^{13}$ (FONAFIFO, 2008).

Regarding the distribution of contracts per type, the largest percentage was dedicated to protection (73.8 percent). Plantations are by far the least numerous type of contract. Geographically, contracts have a fairly decentralized distribution. The region of Arenal-Huetar Norte holds the largest share of contracts (21.6 percent), followed by the Volcanic Central Area (15.5 percent) and the Tempisque region (12.6 percent). These data refer to 1998-2001 (see Table 2).

In its early years, PESP was generally regarded as a successful and efficient initiative for the reduction of deforestation in private lands (Carvajal et al., 2003; Miranda et al., 2003; Snider et al., 2003; De Man, 2004; Tomaselli, 2004; Hope et al., 2005; Kosoy et al., 2005; Zbinden \& Lee, 2005; Pagiola, 2006). The demand for contracts has been steady. On May 20, 2008, FONAFIFO published cumulative data for all contracts signed between 1997 and 2007 - there were 7,242 PES contracts; 1,945,552 trees were planted; 531,959.50 ha were protected and 39,036 ha were reforested. Forest management contracts, discontinued in 2002, benefited 28,066 ha (FONAFIFO, 2008) (see more relevant data in Table 3 ).

TABLE 2 - Costa Rica's PESP: Number of Contracts, by Area and Type, 1998-2001

\begin{tabular}{lcccccc}
\hline \multicolumn{1}{c}{ area } & management & plantations & protection & reforestation & total & (\%) \\
\hline Amistad-Caribe & 11 & 0 & 174 & 26 & 211 & 12 \\
Arenal-Huetar Norte & 91 & 1 & 211 & 75 & 378 & 21.6 \\
Amistad Pacífico & 0 & 0 & 104 & 11 & 115 & 6.6 \\
Arenal Tilarán & 0 & 0 & 84 & 9 & 93 & 5.3 \\
Guanacaste & 11 & 2 & 62 & 2 & 77 & 4.4 \\
Osa & 19 & 0 & 146 & 5 & 139 & 9.7 \\
Pacífico Central & 1 & 1 & 103 & 28 & 212 & 7.7 \\
Tempisque & 0 & 7 & 129 & 46 & 92 & 12.1 \\
Tortuguero & 10 & 4 & 75 & 3 & 271 & 5.3 \\
Volcánica Central & 36 & 2 & 175 & 58 & 17 & 15.5 \\
\hline total & $\mathbf{1 7 9}$ & $\mathbf{1 7}$ & $\mathbf{1 , 2 9 3}$ & $\mathbf{2 6 3}$ & $\mathbf{1 , 7 5 2}$ \\
\hline
\end{tabular}

SOURCE: Carvajal et al. (2003, p. 15).

TABLE 3 - Costa Rica's PESP: Distribution of the Areas Affected by Contracts, by Year and by Category, 1997-2007.

\begin{tabular}{ccccccc}
\hline year & $\begin{array}{c}\text { protection } \\
\text { area (ha) }\end{array}$ & $\begin{array}{c}\text { management } \\
\text { area (ha) }\end{array}$ & $\begin{array}{c}\text { reforestation } \\
\text { area (ha) }\end{array}$ & $\begin{array}{c}\text { total } \\
\text { area (ha) }\end{array}$ & $\begin{array}{c}\text { agroforestry } \\
\text { (planted trees) }\end{array}$ & $\begin{array}{c}\text { number of } \\
\text { contracts }\end{array}$ \\
\hline 1997 & 88,830 & 9,325 & 4,629 & 102,784 & - & 1,200 \\
1998 & 47,804 & 7,620 & 4,173 & 59,916 & - & 597 \\
1999 & 55,776 & 5,125 & 3,156 & 64,781 & - & 622 \\
2000 & 26,583 & - & 2,457 & 29,040 & - & 271 \\
2001 & 20,629 & 3,997 & 3,281 & 27,907 & - & 287 \\
2002 & 21,819 & 1,999 & 1,108 & 24,904 & - & 279 \\
2003 & 65,405 & - & 3,155 & 68,765 & 97,381 & 672 \\
2004 & 71,081 & - & 1,557 & 72,638 & 412,558 & 760 \\
2005 & 53,493 & - & 3,602 & 57,095 & 513,684 & 755 \\
2006 & 19,972 & - & 4,866 & 24,838 & 380,398 & 619 \\
2007 & 60,567 & - & 5,826 & 66,393 & 541,531 & 1,180 \\
\hline total & $\mathbf{5 3 1 , 9 5 9}$ & $\mathbf{2 8 , 0 6 6}$ & $\mathbf{3 9 , 0 3 6}$ & $\mathbf{5 3 2 , 6 8 8}$ & $\mathbf{1 , 9 4 5 , 5 5 2}$ & $\mathbf{7 , 2 4 2}$ \\
\hline
\end{tabular}

SOURCE: FONAFIFO, 2008.

${ }^{13} \mathrm{http}: / /$ www.fonafifo.com/paginas_espanol/servicios_ambientales/sa_estadisticas.htm, June $26^{\text {th }}, 2014$. 
It is clear that PESP made a significant contribution to maintain and restore forest cover in Costa Rica. While the SINAC covers 53.72 percent of the forested area and 25.15 percent of the country's territory (SINAC, 2008), PESP was able to preserve and/or revitalize an additional 25 percent of the country's forested area and 11.73 percent of its territory. Along with lower deforestation rates, these figures show PESP's positive effects.

PESP and SINAC are not the only policies responsible for the sharp fall of deforestation rates in Costa Rica (FAO, 2005, p. 200). The national government points out that forestry management plans imposed on private landowners and other financial incentives given to forestry related activities (income tax deductions, loans with reduced interest, funds to benefit municipalities and organizations, bonds and debentures), discontinued after PESP was launched, also contributed to revert the intense rate of deforestation recorded in the 1960s and 1970s (MINAE, 2002).

\section{The role of institutional strengthening and innovation in governance}

North (1990) and Williamson (1996) have been widely influential in calling attention to the societal gains achieved in many fields by means of institutional organization and improvement and by the establishment of proper governance mechanisms. Even a cursory examination of these matters shows that PESP was accompanied by major changes in the institutional framework and governance connected to land-use planning, forestry management, and conservation. Since 1969, when its first Forest Law was published and its General Forest Council (Dirección General Forestal) was created, Costa Rica has improved its forestry management system. New public policies and innovative financial mechanisms were created and applied. As a result of the significant changes in society's perceptions of management and conservation of natural resources, Costa Rica experienced extensive changes in its legislation, in its institutional structure and in the way governments address market failures (MINAE, 2002). This, of course, created a favorable political and institutional environment for PESP and other environmental policies and programs.

As legislation and agencies were renewed to manage an improved forestry system, both the private and public sectors became aware of the need to create specific mechanisms for government intervention in the economy, in order to revert the weak competitive edge of small producers in the face of agribusiness ${ }^{14}$ (MINAE, 2008). Over the last decades, the government has spent a lot of energy in the regulation of forest management, reforestation, tree plantations, agroforestry systems, timber harvesting and the extraction of non-wood forest products. It also created the SINAC and it introduced new communication channels and new public institutions to connect with the private sector and with society at large to guarantee that stakeholders' interests were taken into account. In addition, it discontinued tax exemptions for the timber industry and created a specific agency and new instruments to raise and channel funds for forest related activities (MINAE, 2002).

The more recent chapter of policy improvement represented by FONAFIFO and the current Costa Rican forestry financing system dates back to the year 1990, with Law 7,174. Its article 24 allowed the creation of trust funds to finance forest related activities conducted by the private sector. ${ }^{15}$ The Fondo Nacional de Financiamiento Forestal - the trust fund FONAFIFO, was created in 1991, based on article 32 of Law 7,216. On April 16, 1996, article 46 of Law 7,575 defined FONAFIFO's duties and consolidated it as the national forest authority (MINAE, 2008). ${ }^{16}$ It is a decentralized body within the Ministry of the Environment and Energy (Ministerio de Ambiente y Energia - MINAE). FONAFIFO has relative autonomy and an instrumental status. Its structure includes a governing board and an executive unit; two representatives from the private sector and three from the public sector, holding two-year terms, compose its board (FONAFIFO, 2008). ${ }^{17}$

\footnotetext{
${ }^{14} \mathrm{http}: / /$ www.minae.go.cr/dependencias/desconcentradas/fondo_nacional_financiamiento_forestal.html, September 152008.

${ }^{15} \mathrm{http}: / /$ www.minae.go.cr/dependencias/desconcentradas/fondo_nacional_financiamiento_forestal.html, September 152008.

${ }^{16} \mathrm{http}: / /$ www.minae.go.cr/dependencias/desconcentradas/fondo_nacional_financiamiento_forestal.html, September 152008.

${ }^{17}$ http://www.fonafifo.com/english.html, January 242013.
} 
In 1997, FONAFIFO launched PESP, which soon became its primary activity (FONAFIFO, 2008). ${ }^{18}$ FONAFIFO manages - through Costa Rica's National Bank - several funds related to PESP: Environmental Services Certificates, Huetar Norte Forestry Program, EcoMarkets and REFORESTA. The Environmental Services Certificates fund is a financial instrument from which FONAFIFO receives resources for PESP, voluntarily provided by different kinds of private companies, in exchange for a certificate. The companies benefit from having their names linked to FONAFIFO and PESP. Businesses quite distinct from each other, such as the Reserva Conchal Hotel, the sugar manufacturer Azucarera El Viejo S.A., the melon producers and exporters Costeña S.A., the Exporpak S.A., the airline company Nature Air and many others joined the program. Companies can choose to place their money in the region from which they receive their environmental services or invest in the conservation of forests in general (FONAFIFO, 2008). ${ }^{19}$

The Huetar Norte Forestry Program is funded by the German government, through the Kreditanstaslt für Wiedderaufbau ( $K f W$ Bankengruppe). It co-finances $70 \%$ of PESP, specifically in the Conservation Area of Huetar Norte and the Sarapiqui Subregion of the Central Volcanic Mountain Range Conservation Area (FONAFIFO, 2008). ${ }^{20}$

The EcoMarkets fund receives money from the Costa Rican government, based on a loan agreement with the World Bank and on donations from the Global Environmental Facility (GEF) and the Japanese government. It helps fund PESP and covers its administration, coordination, development and maintenance of information systems and field supervision. The expanded participation of women and indigenous peoples in PESP is among the goals pursued by EcoMarkets.

Unlike EcoMarkets, REFORESTA is not a source of financing. It is an example of indirect intervention in the forestry market. It aims to finance the development of new wood products, for the purpose of widening their scope and stimulating commercial forest plantations. The Japanese government and the World Bank give financial support to this program. ${ }^{21}$

These funds assure a flow of financial resources that cover PESP's direct payments to beneficiaries. They also assist and support FONAFIFO's technical and administrative structure. As happens with other projects involving foreign, intergovernmental or international funding, possible constraints in the flow of foreign funds may have affected PESP's ability to operate. However, we did not find indications that this happened in its early years. The national government consolidated PESP institutions and regulations. Though PESP ultimately achieved its goal of controlling deforestation and expanding the country's forest cover, in its early years, at least, it did not achieve its goal of providing selective benefits to small and medium landowners. ${ }^{22}$

\section{PESP - a poverty alleviation instrument?}

The last matter to be examined is PESP's potential to generate social, economic and environmental benefits, both directly and indirectly, particularly in the form of poverty alleviation. Direct benefits are quite straightforward: Financial disbursements made to land owners in exchange for the environmental services that their forests provide. The sums received by beneficiaries of course have a wide range of significance in relation to their other sources of income. Such payments are at the heart of the PES concept.

Indirect benefits include other financial and nonfinancial benefits received by individuals, communities and landowners. These benefits, although not necessarily accrued by all beneficiaries, are varied and widespread. The building of social capital among poorer beneficiaries, for example, is an usual outcome of the institutional improvements and participatory mechanisms linked to

\footnotetext{
${ }^{18}$ http://www.fonafifo.com/english.html, January 242013.

${ }^{19} \mathrm{http}: / /$ www.fonafifo.com/paginas_espanol/invierta_bosques/e_ib_invierta_en_bosques.htm, June 262014.

${ }^{20} \mathrm{http}$ ://www.fonafifo.com/paginas_espanol/proyectos/e_pr_kfw.htm, June $26 \overline{2014}$.

${ }^{21} \mathrm{http}: / /$ www.fonafifo.com/paginas_espanol/proyectos/e_pr_reforesta.htm, June 262014.

${ }^{22}$ http://www.fonafifo.com/index.html, accessed on June 262014.
} 
PES programs. Additionally, access to PES programs through collective contracts, adopted right after the early years of PESP, substantially reduced red-tape procedures and other transaction costs that affected the Costa Rican poor more than proportionally. When PESP let go of the requirement of land entitlement documents to be admitted in the program it also created indirect benefits for the rural poor. One last example to be cited here as an indirect benefit is the provision of credit for investments required for fulfilling PES contracts. This is especially relevant for reforestation contracts, in which landowners need to make early investments in equipment, seedlings and machinery (Miranda et al., 2003). ${ }^{23}$

Although the ultimate goal of PESP is to promote forest protection (MINAE, 2002, p. 39), FONAFIFO states that it was designed "to benefit small and mediumsized landowners" (FONAFIFO, 2008) ${ }^{24}$. Unfortunately, despite this statement and PESP's potential to fulfill it, the program has not been managed as a poverty mitigation tool, as attested by several case studies that examined its early years (Carvajal et al., 2003; Miranda et al., 2003; Snider et al., 2003; De Man, 2004; Hope et al., 2005; Kosoy et al., 2005; Zbinden \& Lee, 2005).

It is significant that no comprehensive official data regarding specifically PESP's socioeconomic effects have been released to date. The only sources of information about these effects are a handful of field studies based on small samples of PESP beneficiaries, undertaken by specialists who focused on the first years of the program. They were funded mostly by international organizations, such as the International Institute for Environment and Development (IIED) and the United Kingdom's Department for International Development (DFID) (Carvajal et al., 2003; Miranda et al., 2003; Zbinden \& Lee, 2005). We will examine their arguments and findings, specifically in relation to the issue of poverty alleviation.

In 2002, Miranda et al. (2003) conducted a survey with a sample of 46 landowners, of whom 32 were receiving payments for environmental services and 14 were not. The sample was randomly selected in the Virilla watershed, located in the Central Volcanic Mountain Range Conservation Area. Several positive PESP side effects were recorded by the survey: protection against squatters; creation of technical and professional posts in forest related activities; provision of technical assistance; training in agro-conservation and management; environmental education, specially for children; support to community organization and networking; capacity building in solid waste management; aquifer protection, and recovery of degraded areas (Miranda et al., 2003, p. 27-38). This is a quite impressive array of side benefits. However, we are interested here in the direct financial benefits, in order to assess if PESP is working as a direct instrument of poverty mitigation.

Miranda et al. (2003) showed that the living standards of interviewed landowners benefitted by PESP are "relatively high", although this finding is not necessarily valid for the bulk of its beneficiaries. They found that 64 percent of landholders with less than 10 ha did not access PESP, while 100 percent of landowners with properties over 80 ha did. For medium size properties (from 11 to $80 \mathrm{ha}$ ), the figure for beneficiaries in the sample was 75 percent (see Table 4).

Although the findings of Miranda et al. (2003) are not necessarily valid for the national scale, their study provides telling figures about PESP beneficiaries. Because payments are computed by area, 17 small and medium landowners (properties with less than $81 \mathrm{ha}$ ) received only 6.92 percent of the total benefits, while 15 landowners with properties larger than 81 ha received around 93 percent.

Another regional sample, studied by De Man (2004), reached similar findings. PESP contracts in the Aranjuez watershed did not favor small landowners because most payments were made to "large landowners". De Man noted that the obstacles to a more inclusive program in that region are complex. The expensive bureaucratic procedures required to enroll in the program and to gain access to detailed information are barriers

\footnotetext{
${ }^{23}$ See also Stefano Pagiola, Agustin Arcenas, and Gunars Platais, Ensuring that the Poor Benefit from Payments for Environmental Services . Environment Department, World Bank [draft]. 2003. Available at http://moderncms.ecosystemmarketplace.com/repository/moderncms_documents/Pagiola,Arcenas,Platais\%20\%20EnsuringBenifitsPoor.pdf, Ocotber 152014.

${ }^{24} \mathrm{http}$ ://www.fonafifo.com, accessed on June 262014.
} 
TABLE 4 - Costa Rica's PESP: Number and Total Area of Properties in the Virilla Watershed Sample Enrolled in 2002, by Property Size.

\begin{tabular}{|c|c|c|c|c|}
\hline property sizes & $\begin{array}{l}\text { number of } \\
\text { properties }\end{array}$ & $\begin{array}{c}\text { enrolled } \\
\text { properties }\end{array}$ & $\begin{array}{c}\text { non-enrolled } \\
\text { properties }\end{array}$ & total area enrolled in PESP \\
\hline less than 10 ha & 14 & 5 & 9 & 50 ha** $^{* *}$ \\
\hline 31 to 80 ha & 9 & 7 & 2 & 560 ha** $^{* *}$ \\
\hline 81 to 130 ha & 6 & 6 & 0 & 780 ha** \\
\hline more than 131 ha & 9 & 9 & 0 & 1,350 ha*** \\
\hline
\end{tabular}

* information unavailable about the size of one property;

** considering the maximum possible area at each level;

*** considering an average of 150 ha for each property.

SOURCE: Adapted from Miranda et al. (2003, p. 21).

to entry. This is not uncommon in PES projects and in several kinds of community-based or "demonstration" projects" targeted at local development and/or environmental protection. Benefits tend to accrue to well informed, better-organized and better-connected actors. In addition, middlemen give priority to large landowners because they charge a percentage of the payment for helping them with bureaucratic demands. Since 2003, however, access became easier, because land titles ceased to be a requirement for soliciting PESP benefits (Carvajal et al., 2003, p. iii). This "inclusive" measure allowed thousands of generally poorer untitled landowners all over the country to become PESP beneficiaries, broadening the area under protection and the social reach of the program.

The survey conducted by Miranda et al. (2003) provides also important information about how PESP impacts income distribution among farmers (Miranda et al., 2003, p. 25). For most beneficiaries (93 percent), PESP payments are the second or even the third most important source of income; only 6 percent have these payments as their main source of income. For larger landowners, the main sources of income are livestock (31 percent), other professional activities (28 percent) and commerce (22 percent). In short, 59 percent of the main sources of income of PESP beneficiaries studied by Miranda et al are not related to farming activities. In contrast, 85 percent of landowners who do not participate in PESP have their major source of income in farm activities (64 percent from livestock; 21 percent from agriculture). Livestock is the main source of income for both beneficiaries ( 31 percent) and non-beneficiaries (64 percent) of PESP. Even among landowners who receive money for forest protection, livestock represents the largest share of their income, even more than professional income.

These data allow the inference that an important share of PESP beneficiaries does not depend on rural activities for their livelihood. In comparison, payments were not widely made to those who are primarily farmers. In addition, Miranda et al. (2003, p. 1) found that beneficiaries were "relatively wealthy and well educated". This indicates that PESP was not being used in its early years as a poverty alleviation strategy, despite its potential to do so.

Another relevant study, by Zbinden \& Lee (2005), compared 106 participants and 142 non-participants in PESP, owners of areas larger than 5 hectares, randomly selected in the northern part of Costa Rica (San Carlos and Los Chiles, in the Sarapiqui region). Results showed that local landowners with large farms are much more likely to participate in all types of PESP contracts than smaller landowners. In this sample, contracts in the forest protection category were limited to properties with more than 50 hectares. Among the farms larger than 100 hectares, only 7 percent were not enrolled in the program, while in small properties the percentages of non-participants were significantly higher: 32 percent of those with properties with less than 10 hectares; 19 percent of those with properties in the range of 10 to 19.9 hectares; and 25 percent of those with mediumsized properties (between 20 and 49.9 ha) (see Figure 1). 


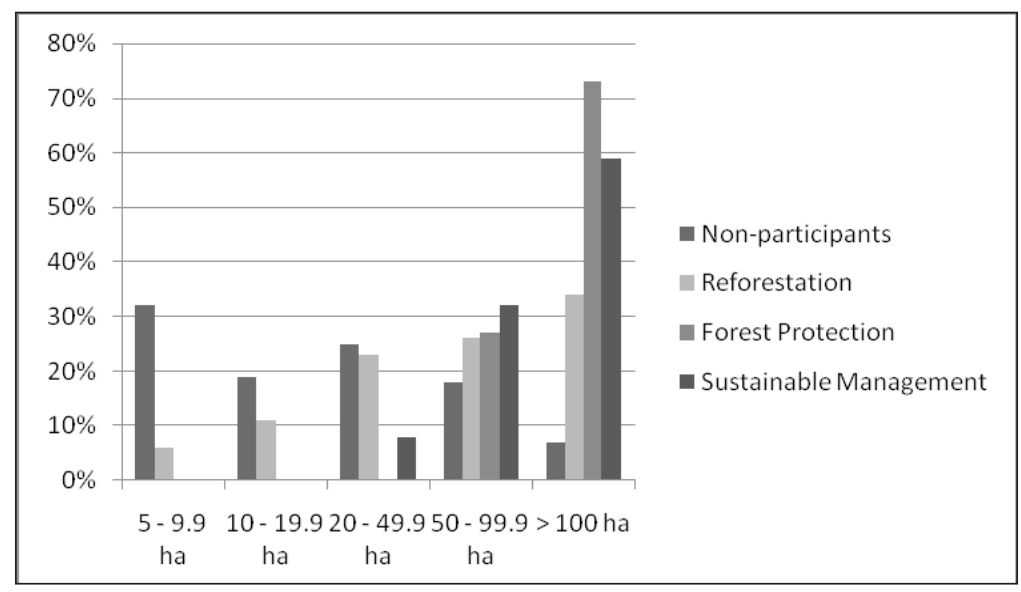

FIGURE 1 - Costa Rica: Participation in PESP in San Carlos and Los Chiles (Sarapiqui), by Type of Contract and Property Size, 2003. (\%)

SOURCE: Adapted from Zbinden \& Lee, 2005.

Carvajal et al. (2003) conducted another survey, this one at the national level, yielding results about the social impacts of PESP. The results are valid on a national scale. It was conducted in 2002 , exactly when the pro- gram completed five years and when the first contracts ended. Data related to the sample of 1,752 contracts are reproduced in Figure 2, showing the number of contracts by size and type of beneficiary.

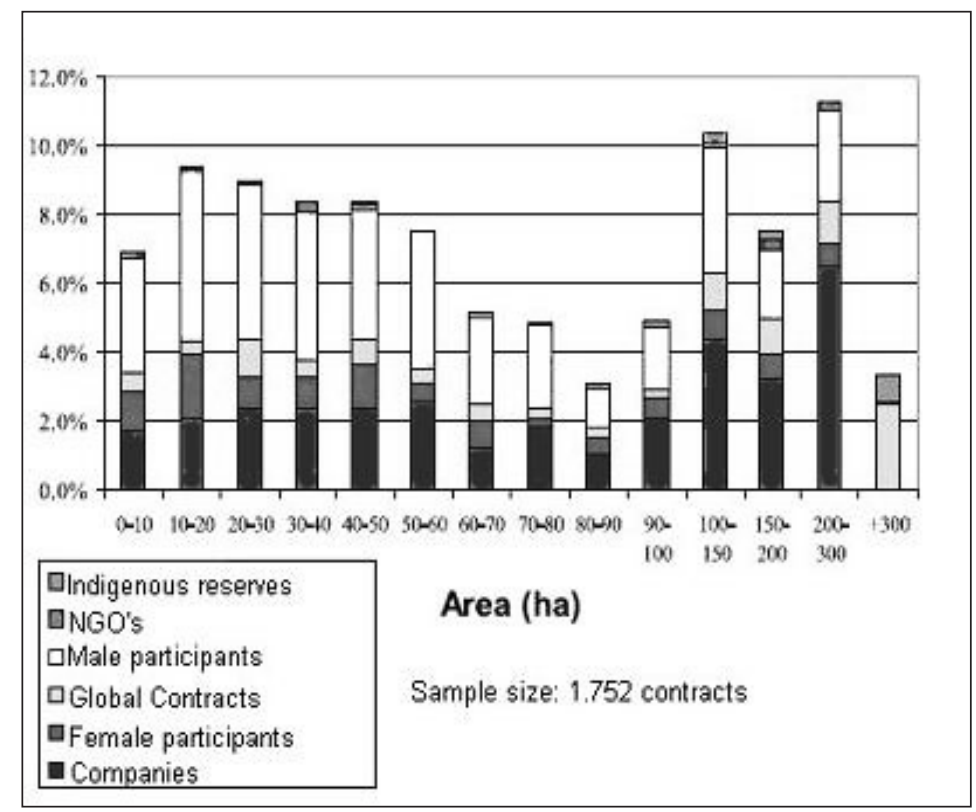

FIGURE 2 - Costa Rica: PESP contracts, by size of property and type of beneficiary, 1997- 2002.

SOURCE: Adapted from Carvajal et al. (2003, p. 12). 
There is a gradual reduction in the incidence of contracts as property areas increase from 10 hectares to 90 hectares. This first group of properties represents approximately 62 percent of PESP contracts. A second group (34 percent) is made of companies with properties between 90 and 300 hectares. The third and smallest group (4 percent) is made of "global" contracts with community associations that jointly hold more than 300 hectares. Although these contracts are signed with the associations, the real beneficiaries are small landowners (properties with less than 50 hectares) (see Figure 3).

This study allows the conclusion that the financial disbursement pattern at the national level follows the same trend found in the Virilla watershed; most contracts were signed with small landowners, but most of the money was paid to beneficiaries who owned large properties.

Considering all PESP contracts signed with owners of properties between 10 and 90 hectares, 1,082 of them shared the total amount paid for 47,420 ha, an average of 43.82 hectares per owner. Those enrolled in the protection category would receive around US\$ 14,000 for a five-year contract - US\$2,800 annually; if they signed reforestation contracts, each would get US\$ 35,000 over a five-year period. Regarding the second group, each of the 670 landholders with properties between

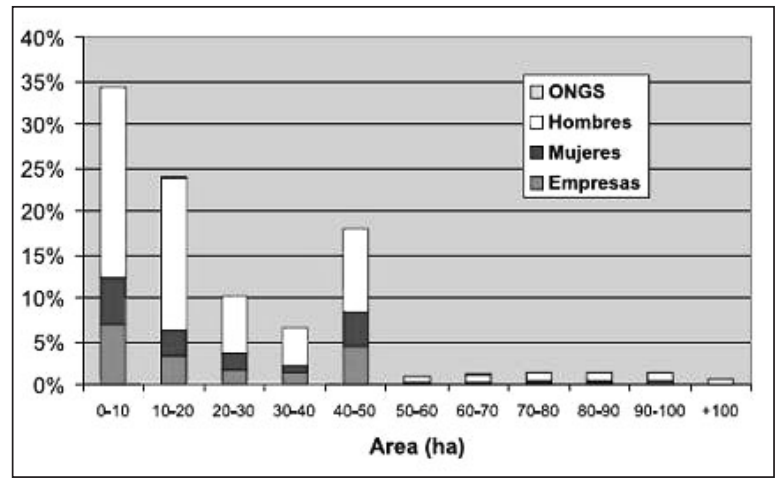

FIGURE 3 - Costa Rica: Categories of PESP Beneficiaries, by Property Size, 1998-2000 (\%)

SOURCE: Carvajal et al. (2003, p. 13).
90 and 300 hectares would be rewarded for conserving an average of 183.5 ha. They would have an annual income of around US\$ 11,800 (US\$ 58,720 for a fiveyear contract) or almost US\$150,000 for a reforestation agreement. Therefore, a large landowner would receive four times more than a small one. In addition, all small properties together would receive 2.5 times less money than the group of large properties. The logic is clear: the larger the area under contract with PESP, the higher the reward $^{25}$ (see Table 5).

TABLE 5 - Costa Rica's PESP: Estimated Total Areas Enrolled and Number of Contracts, by Property Size, 2002

\begin{tabular}{|c|c|c|}
\hline size of property & $\begin{array}{l}\text { number of } \\
\text { contracts* }\end{array}$ & $\begin{array}{l}\text { total area } \\
\text { in PESP } \\
\text { (ha)** }\end{array}$ \\
\hline $0-10$ ha & 123 & 1,230 \\
\hline $10-20$ ha & 163 & 3,260 \\
\hline $20-30$ ha & 157 & 4,710 \\
\hline $30-40$ ha & 143 & 5,720 \\
\hline $40-50$ ha & 142 & 7,100 \\
\hline $50-60$ ha & 126 & 7,560 \\
\hline $60-70$ ha & 90 & 6,300 \\
\hline $70-80$ ha & 88 & 7,040 \\
\hline $80-90$ ha & 50 & 4,500 \\
\hline sub-total (10-90 ha) & 1,082 & 47,420 \\
\hline $90-100$ ha & 91 & 9,100 \\
\hline $100-150$ ha & 181 & 27,150 \\
\hline $150-200$ ha & 135 & 27,000 \\
\hline 200-300 ha & 199 & 59,700 \\
\hline sub-total (90-300 ha) & 670 & 122,950 \\
\hline 300 or more ha & 64 & 19,200 \\
\hline total & 1,752 & 189,570 \\
\hline
\end{tabular}

Furthermore, data collected by Carvajal et al. (2003) show that PESP contracts demand or lead to changes in land use in only a limited number of cases. The data in Table 6 show that 43 percent of PESP beneficiaries were already protecting natural resources on

\footnotetext{
${ }^{25}$ For an emphatic critique of the concept of both REDD and PES projects in connection with this problem of favoring large landowners and thus forgiving their "sins", see Valny Giacomelli Sobrinho, REDD Roses for a Green Lady - Target Setting for Deforestation in the Brazilian Amazon, available at $<$ http://www.intechopen.com/books/co2-sequestration-and-valorization/redd-roses-for-a-green-lady-target-setting-fordeforestation-in-the-brazilian-amazon>, accessed on October 142014.
} 
their lands before enrolling in the program, while 49 percent were using their land for cattle ranching, agriculture or timber harvesting. This large percentage (43 percent) of protected forests extent in private properties prior to PESP is probably linked to the fact that most of their owners do not derive their major income from farms, as ascertained by Miranda et al. (2003). Regarding these landowners, government intervention through PESP contracts does not affect the conservation status of their properties, since they would probably maintain forest cover on their properties without PESP. Kosoy et al. (2005, p. 11) made a similar finding, studying PESP beneficiaries in the Heredia region. They concluded that landowners who do not depend on rural productive activities for their livelihoods will "in any case keep the remaining forest cover of their land (...), in part because forests provide leisure and scenery to them", with or without PESP.

TABLE 6 - Costa Rica's PESP: Percentages of Beneficiaries who changed from Agriculture, Cattle Ranching or Other Land Uses to PESP Uses, 2002

\begin{tabular}{lc}
\hline \multicolumn{1}{c}{ previous use } & percentages \\
\hline PESP uses & 43 \\
cattle ranching & 36 \\
agriculture & 7 \\
logging & 6 \\
no use & 6 \\
no answer & 2 \\
\hline \multicolumn{1}{c}{ total } & $\mathbf{1 0 0}$ \\
\hline
\end{tabular}

SOURCE: Adapted from Carvajal et al. (2003, p. 31).

Regarding the remaining 57 percent of the beneficiaries sampled by Miranda et al. (2003), we conclude that PESP was more than moderately successful in addressing market failures. If these farmers stopped using their lands for cattle ranching, agriculture and timber harvesting, payments made by FONAFIFO were probably equal or higher than the profits to be derived from those land uses.

Additionally, the data in Table 7 reflect the answers given to the question "If PESP did not exist, what would you do with your property?", asked by Carvajal et al. (2003): 45 percent of respondents said that they would designate the areas on their properties for conservation purposes, independently of PESP.
TABLE 7 - Costa Rica's PESP: Answers given to the question "If PESP did not exist, what would you do with your property?"

\begin{tabular}{lc}
\hline \multicolumn{1}{c}{ answers } & percentage \\
\hline conservation & 45 \\
pastures & 17 \\
sell the property & 12 \\
logging & 8 \\
agriculture & 5 \\
eco-tourism & 2 \\
nothing & 5 \\
no answer/does not know & 6 \\
\hline total & $\mathbf{1 0 0}$ \\
\hline
\end{tabular}

SOURCE: Adapted from Carvajal et al. (2003, p. 39).

These findings show that PESP does not necessarily shape landowners' conservationist behavior in the long run. Conservation efforts would probably be made privately after PESP implementation by the same landowners who were protecting their lands before the program. These findings also underline the fact that the program manages to correct market failures in some cases, as landowners who would exploit natural resources even if there were no financial rewards for protecting them change their behavior when benefited by PESP.

Based on these case studies, we conclude that PESP would be more efficient if it selectively targeted private properties strongly threatened by deforestation, such as those in which agriculture, cattle ranching and timber harvesting generate the major portions of household income. In addition to attaining stronger conservation effects in these types of properties, early PESP initiatives could have been used as an intentional poverty mitigation strategy, if small and poor landowners had been its major target groups.

\section{Final Remarks}

We conclude that PESP encourages forest protection in private properties, but we see also that the program faces several challenges in terms of related or potentially related effects. We examined official data and several case studies to conclude that the program succeeds in reverting land use from clear cutting to forest conservation because it corrects market failures. Addi- 
tionally, it was found that its implementation was aided by legal improvements and institutional reinforcements that occurred over the last two decades.

PESP created new trade opportunities linked to the market of environmental services. Before the program, landowners whose income depended mainly on rural activities would not protect their forests mostly because this decision would restrict profitable activities in agriculture, cattle ranching or timber harvesting. Now they are financially rewarded for protecting portions of their forests in order to provide environmental goods and services. Moreover, they can make their lands even more profitable if they explore all these possibilities, according to their forest management plans or using innovative production systems, such as agroforestry.

PESP would have a much wider social impact, though, if it did not benefit mostly landowners who would protect natural resources even if the program did not exist. To interrupt this trend, the program should give a priority status to privately owned areas that face a high threat of deforestation, commonly used for productive activities that generate most of the household income. Besides, the program's potential of becoming a poverty mitigation strategy is not being well used, since a bigger share of payments is made to large landowners, many of whose incomes do not depend strongly on rural activities.

Although PESP was not designed for poverty mitigation, this could be a significant addition to its success, but this requires design improvement. According to some of the studies contained in Angelsen (2012), this has been a major cause for the lack of popularity or the failing of PES projects. Improvements require attention to important details. First, the selection of beneficiaries must change. Managers should consider not only the risk of deforestation and opportunity costs of forest conservation, but also the economic and social profile of landowners and communities. Defining a tighter profile of potential beneficiaries, with priority given to poorer

\section{References}

Aguilar-Støen, M.; Okamoto, T.; Rosendal, G. K.; Schei, P. J. From PES to REDD? Emerging actors, alliances and conflicts in Colombia and Costa Rica. Unpublished paper, 2013. rural landowners, can accomplish this. Second, making information about the program widely available would also help, so that targeted communities could participate proactively. A third measure would be the simplification of bureaucratic procedures, especially for small and medium landowners with relatively low income. A fourth measure would be to partially disconnect PESP payments from the sizes of the areas under protection or recovery, because the criterion of "larger properties, higher payments" obviously favors large landowners. This could be accomplished by introducing one or more correction factors taking into account the income of beneficiaries and/or the small sizes of their properties, besides the sizes of protected areas. This would direct more payments to small landowners. The Costa Rican government has already moved in the direction of some of these measures. Since 2003, for example, indigenous communities began to be accepted in PESP, land titles ceased to be required, and collective contracts with small landowners' associations became a priority goal.

Two matters that were not pursued here deserve attention in future assessments of PESP: (i) What proportion of the federal Costa Rican budget has been spent with PESP payments? (ii) What has been PESP's net welfare gain? (iii). Answering these two question of course means making an overall evaluation of the costs of this financing scheme to Costa Rican government and society? Such an effort will be more fruitfully pursued if the entire life span of the program is placed under examination, because long-term trends will probably have set in.

Based on its status of a pioneer PES program and on its success, PESP can become an even stronger model for other developing countries with similar socioeconomic and environmental problems, not only as a mechanism to lower deforestation rates, change land uses and expand forest cover, but also as a poverty mitigation instrument.

Angelsen, A. (Ed.). Analyzing REDD+ - Challenges and Choices. Bogor, Indonesia: CIFOR, 2012.

Butler, R. A Conservationist Sees Signs of Hope for the World's Rainforests. Yale environment360. <http://e360.yale. edu/mobile/feature.msp?id=2822> Accessed on April 202015. 
Carvajal, C. B.; Malavasi, E. O.; Mora, L. F. S. Impacto del Programa de Pago de Servicios Ambientales en Costa Rica como medio de reducción de la pobreza en los medios rurales. San José, Costa Rica, 2003.

COSTA RICA. Octavo Informe sobre el Estado de la Nación. San José, Costa Rica, 2002.

COSTA RICA. Décimo Tercero Informe sobre el Estado de la Nación. San José, Costa Rica, 2007.

Daly, H. Beyond Growth - the economics of sustainable development. Boston: Beacon Press, 1996.

De Man, M. Local impacts and effectiveness of Payments for Environmental Services in Costa Rica: The case of payments for forest hydrological services in Costa Rica's Aranjuez watershed. Copernicus Institute, Universiteit Utrecht. December, 2004.

Eloy, L.; Coudel, E.; Toni, F. Implementando Pagamentos por Serviços Ambientais no Brasil: caminhos para uma reflexão crítica. Sustentabilidade em Debate, 4(1), 21-42, 2013.

FAO. Global Forest Resources Assessment 2005: Progress towards sustainable forest management. FAO Forestry Paper n. 147. Food and Agriculture Organization of the United Nations. Rome, 2005.

Ferraro, P. J.; Kiss, A. Direct Payments to Conserve Biodiversity. Science, 298(5599), 1718-1719, 2002.

FONAFIFO. Manual de procedimientos para el pago de servicios ambientales. San José, Costa Rica, 2003.

FONAFIFO. Manual de procedimientos para el pago de servicios ambientales. San José, Costa Rica, 2006.

FONAFIFO. Manual de procedimientos para el pago de servicios ambientales. San José, Costa Rica, 2007.

FONAFIFO. Manual de procedimientos para el pago de servicios ambientales. San José, Costa Rica, 2008.

Hope, R. A.; Porras, I. T.; Miranda, M. Can payments for environmental services contribute to poverty reduction? A livelihood analysis from Arenal. Costa Rica. February, 2005.

Kosoy, N.; Martinez-Tuna, M.; Muradian, R.; Martinez-Alier, J. Payments for environmental services in watersheds: insights from a comparative study of two cases in Central America. Seminar on environmental services and financing for the protection and sustainable use of ecosystems. Geneva, 10-11 October 2005.

Le Coq, J-F; Froger, G.; Legrand, T.; Pesche, D.; Saenz, F. Continuity and Inflexions of the Program of Payment for
Environmental Services in Costa Rica: A Learning Process and Stakeholders' Balance of Power Perspective. SERENA Document de travail $\mathrm{n}^{\circ}$ 2011-10. 2011. Available at: http:// www.serena-anr.org/IMG/pdf/WP_gouvernance_PES_final_WP2011-10.pdf. Accessed on: June 272014.

Le Coq, J-F; Pesche, D.; Legrand, T.; Froger, G.; Segura, F. S. La mise en politique des services environnementaux: la genèse du programme de paiements pour services environnementaux au Costa Rica, VertigO - la revue électronique en sciences de l'environnement [Online], Volume 12 numéro 3 | décembre 2012. Online since 15 December 2012, connection on 21 April 2015. URL: http://vertigo.revues.org/12920 ; DOI: 10.4000/ vertigo. 12920

Lustosa, M. C. J.; Cánepa, E. M.; Young, C. E. F. Política Ambiental. In: May, P. H.; Lustosa, M. C. J.; Vinha, V. da (Orgs.). Economia do meio ambiente: teoria e prática. Rio de Janeiro: Elsevier, 2003.

MAG/MIRENEM. Ministerio de Agricultura y Ganadería (MAG) Ministerio de Recursos Naturales, Energía y Minas (MIRENEM). Metodología Para La Determinación de La Capacidad de Uso de Las Tierras de Costa Rica. 1995, San José, Costa Rica, p. 12-18.

MINAE. El éxito forestal de Costa Rica en cinco casos. Ministério de Ambiente y Energía. Comisión de Seguimiento del Plan Nacional de Desarollo Forestal. San José, Costa Rica, 2002.

MINAE. Decreto 31,767-MINAE. Ministério de Ambiente y Energía. Comisión de Seguimiento del Plan Nacional de Desarollo Forestal. San José, Costa Rica, 2004.

MINAE. Decreto 33,226-MINAE. Ministério de Ambiente y Energía. Comisión de Seguimiento del Plan Nacional de Desarollo Forestal. San José, Costa Rica, 2006.

MINAE. Decreto 33,852-MINAE. Ministério de Ambiente y Energía. Comisión de Seguimiento del Plan Nacional de Desarollo Forestal. San José, Costa Rica, 2007.

MINAE. Decreto 34,371-MINAE. Ministério de Ambiente y Energía. Comisión de Seguimiento del Plan Nacional de Desarollo Forestal. San José, Costa Rica, 2008.

Miranda, M.; Porras, I. T.; Moreno, M. L. The social impacts of payments for environmental services in Costa Rica: A quantitative field survey and analysis of the Virilla watershed. United Kingdom, International Institute for Environment and Development (IIED), October 2003.

North, D. C. Institutions, Institutional Change and Economic Performance. New York: Cambridge University Press, 1990. 
Pagiola, S. Payments for environmental services in Costa Rica. Washington, (DC): World Bank. (MPRA Paper nº. 2010), 2006. Available at: http://mpra.ub.uni-muenchen.de/2010/. Accessed on: June 272014.

Palm, V.; Larsson, M. Economic instruments and environmental accounts. Ecological Economics, 65, 68-92, 2007.

Pereira, S. N. C. Payment for Environmental Services in the Amazon Forest: How Can Conservation and Development Be Reconciled? The Journal of Environment \& Development, 19(2), 171-190, 2010. doi: 10.1177/1070496510368047

Persson A.; Munasinghe, M. Natural Resource Management and Economy-wide Policies in Costa Rica: A Computable General Equilibrium (CGE) Modelling Approach. World Bank Econ Rev (1995) 9(2), 259-285. doi: 10.1093/wber/9.2.259

Rojas, M.; Aylward, B. What Are We Learning from Experiences with Markets for Environmental Services in Costa Rica? A Review and Critique of the Literature. International Institute for Environment and Development. London: 2003.

Romeiro, A. R. Economia ou Economia Política da Sustentabilidade. In: May, P. H.; Lustosa, M. C. J.; Vinha, V. da (Orgs.). Economia do meio ambiente: teoria e prática. Rio de Janeiro: Elsevier, 2003.

Rosero-Bixby, L.; Poloni, A. Population and Deforestation in Costa Rica. Population and Environment. 20(2), 149-185, 1998.

SINAC - Sistema Nacional de Áreas de Conservación. El Sistema Nacional de Áreas de Conservación: Evolución y
Perspectivas. 2008. Available at: documentacion.sirefor.go.cr/ archivo/boletines_sinac/sinac_perspectivas.pdf. Accessed on: 9 Oct. 2008. 19:40.

Snider, A. G.; Pattanayak, S. K.; Sills, E. O.; Schuler, J. L. Policy innovations for private forest management and conservation in Costa Rica. Journal of Forestry, 101, no 5 , 18-23, July-August 2003.

Stavins, R. N. Experience with Market-Based Environmental Policy Instruments. The Fondazione Eni Enrico Mattei Note di Lavoro Series. 2002. Available at: http://www.feem.it/web/ activ/_activ.html. Accessed on: Oct. 13rd, 2008.

Tomaselli, I. Lessons from Latin America and their relevance to SFM in Africa. African Forest Research Network (AFORNET) at Royal Swedish Academy of Agriculture and Forestry (KSLA). Curitiba, Brazil. August, 2004.

Ulate, G. V. La vegetación de américa central: características, transformaciones y protección. Anuario de Estudios Centroamericanos. 23(1-2), 7-34, 1997.

Williamson, O. E. The Mechanisms of Governance. Oxford: Oxford University Press, 1996.

Wunder, S. Payment for environmental services: some nuts some bolts. Center for International Forestry Research, 2005.

Zbinden, S.; Lee, D. R. Paying for Environmental Services: An Analysis of Participation in Costa Rica's PSA Program. World Development, 33(2), 255-272, 2005. 